\title{
A Review of Plastics Use in Winemaking: HACCP Considerations
}

\author{
Cassandra M. Plank ${ }^{1}$ and Brent C. Trela ${ }^{2 *}$
}

\begin{abstract}
Use of plastics is ubiquitous in the food and beverage industries, with expanding usage in wine production. Common plastic additives, used to modify and improve applicability and durability of plastics, include phthalate plasticizers and bisphenols. Phthalates are used in many products, including polyvinyl chloride (PVC), lubricants, and emulsifying agents. Bisphenols such as bisphenol A (BPA) and related BPA non-intent (BPA-NI) alternatives are used to harden plastics and are commonly used in polycarbonate plastics and epoxy coatings. Migration of bisphenols and plasticizers into wine from plastic containers and closures has been studied using analytical tools such as gas chromatography-mass spectrometry and liquid chromatography-mass spectrometry. Foodstuffs can become contaminated with plastic additives through food-contact processing and packaging materials, leading to environmental and human health concerns. This work reviews current food product use and regulations regarding plastic additives and potential leachates, particularly in wines, hazard analysis and critical control points approaches, alternative plasticizers, and bio-based plastics.
\end{abstract}

Key words: bisphenol, epoxy, leachate, packaging, phthalate, plasticizer

Due to their malleability, versatility, and low cost, plastics have become ubiquitous in present day products. Foodstuffs may contact plastics through many pathways, including food packaging, long-term product storage, and food transportation. Plastics are increasingly used in wine processing and packaging materials. Annually, $\sim 8 \%$ of the world's oil production goes toward producing the $\sim 250$ million $\mathrm{t}_{\mathrm{m}}$ of plastics used globally, of which roughly $30 \%$ is used for packaging (Robertson 2013). Plastics are considered biochemically inert and unable to penetrate through cell membranes because of their large molecular size, preventing them from interacting with the endocrine system. Nevertheless, plastics can also contain additives, unreacted feedstock monomers or oligomers of the component plastics, and non-intentionally added substances (NIAS), which include plastic degradation products and other potential chemical side reactions from the manufacturing process (Teuten et al. 2009, Paseiro-Cerrato et al. 2017). These could potentially migrate into the wine with biological consequences, and may pose a food safety risk or otherwise be of concern to the quality or marketability of wine.

The goal of food safety practices is to limit the presence of food-borne hazards in food at the point of consumption. Food safety hazards are usually the result of physical, chemical, or biological factors. Since food safety hazards can occur

\footnotetext{
${ }^{1}$ Department of Viticulture and Enology, University of California, Davis, 1 Shields Avenue, Davis, CA 95616; and ${ }^{2} 1408$ N 28th St., Renton, WA 98056.

*Corresponding author (tel: $+1.806 .252 .6568)$

Acknowledgments: The authors declare no competing financial interest.

Manuscript submitted May 2017; revised Dec 2017, Jan 2018, June 2018; accepted June 2018

Copyright (C) 2018 by the American Society for Enology and Viticulture. All rights reserved.

doi: 10.5344/ajev.2018.17041
}

at any stage in the food chain, it is essential that adequate controls be in place. Hazard analysis critical control points (HACCP) and quality assurance systems like the International Standardization Organization (ISO) 9000 series, and its food safety derivative ISO 22000 , have been developed to prevent food safety risks and consequently provide a competitive advantage to producers that implement such systems (ISO 2005). The purpose of this review is to identify potential plastics-related hazards in wine that could be addressed by HACCP principles. Scalping, sorption, permeation, and effects on product quality by plastic additives and wine are not the focus of this work and will be expanded upon in a follow-up review.

\section{Review of Plastics}

Plastics are synthetic or semi-synthetic polymers made from a wide range of moldable organic polymers set into a rigid or semi-elastic solid. The physical and chemical properties of the plastic are determined by its geometric structure, including conformation, configuration, and branching of polymeric chains, and by the degree of crosslinking with itself or other molecules. Properties of polymers, including density, thickness, and transition temperatures, are determined by their molecular composition and structure, molecular weight, and degree of crystallinity, which affects optical transparency in plastics (Krimm and Tobolsky 1951, Robertson 2013). Molecular orientation of polymer chains determines whether plastics are amorphous or semi-crystalline (White and Spruiell 1981, Robertson 2013). Amorphous polymer chains are disordered, have no melting point, and gradually soften with increasing temperature. Examples of amorphous polymer chains include polystyrene (PS) and polyvinyl chloride (PVC). In contrast, semi-crystalline polymers usually exhibit distinct phase transition temperatures: a sharp melting and glass transition temperature $\left(\mathrm{T}_{\mathrm{g}}\right)$ such as polyethylene $(\mathrm{PE})$ and polypropylene 
(PP). PE and PP are two of the most common thermoplastics and belong to a class of polymers called the polyolefins (Piringer and Baner 2008).

Plastic polymers can be divided into three categories: thermoplastics, theromosets, and elastomers (Klein 2011; Figure 1). Thermoplastics consist of long, linear, saturated carbon-carbon chains that extend in one dimension. Molecular chains of thermoplastics can move independently because they are not crosslinked. Thermoplastics can be reused because they can be repeatedly melted and solidified by heating and cooling (Robertson 2013). Unlike thermoplastics, thermosets form irreversible crosslinks between chains during processing and cannot be re-melted and reprocessed (Lithner et al. 2011, Robertson 2013). Elastomers share properties of thermoplastics and thermosets. Elastomers have wide crosslinks between molecules, which allow mobility of molecular chains resulting in soft and elastic properties. Rising temperature increases elasticity, but like thermosets, they cannot be melted without thermal decomposition (Shanks and Kong 2013).

Due to their mechanical properties, thermoplastics are the most widely used plastics, accounting for more than two-thirds of all polymers used globally (Robertson 2013). Common thermoplastics belong to a few generic plastic resin families identified by the Resin Identification Codes that aid sorting and recycling in the waste stream (Table 1) (D20 Committee 2010). The current ASTM D7611 gives codes for the six most commonly found resin types, numbered in order from one to six: polyethylene terephthalate (PETE, PET), high-density PE (HDPE), PVC (V), low-density PE (LDPE), $\mathrm{PP}$, and PS. All other resins, including PC, acrylonitrile butadiene styrene (ABS), nylon, and other materials made with more than one type of resin are marked with a No. 7 (ASTM International 2013).

\section{Plastic Ingredients}

Plastic additives. To increase the strength and consistency of plastics, additives such as stabilizers, plasticizers, biocides, flame retardants, and pigments are added. Additives can act as filler (e.g., carbonates and silicates) to extend the volume of material and reduce production costs (Deanin 1975). Stabilizers may include hydrogen-donating antioxidants (e.g., hindered phenols and secondary aromatic amines), hydroperoxide decomposers (e.g., organosulfur compounds), heat stabilizers (e.g., lead, tin, and mixed-metal compounds such as calcium-zinc), light stabilizers (e.g., hindered amine light stabilizers [HALS]), and UV absorbers (e.g., benzophenones) that inhibit formation of free radicals and photo-oxidation reactions such as those catalyzed by UV irradiation (Ceresana 2011a, 2012, 2013). Pigments are used as colorants and may also confer additional properties such as UV protection (e.g., titanium dioxide and carbon black) (Ceresana 2011b, Lithner et al. 2011). Biocide examples include halogen, metallic, and organosulfur compounds (Ceresana 2012). Fire retardants may be added to reduce flammability (e.g., organic halogen compounds and magnesium hydroxide) (Ceresana 2011c). Various lubricants such as paraffin and other petrochemical waxes and oils may also be added to the polymers or surfaces of machine processing parts during plastics manufacturing.

Phthalate plasticizers. One of the largest and most controversial groups of plastic additives is plasticizers. Phthalate ester plasticizers are the most common (Table 2) and were first used commercially in the 1920s (Graham 1973, Guo et al. 2012). Plasticizers are organic compounds added to plastics to

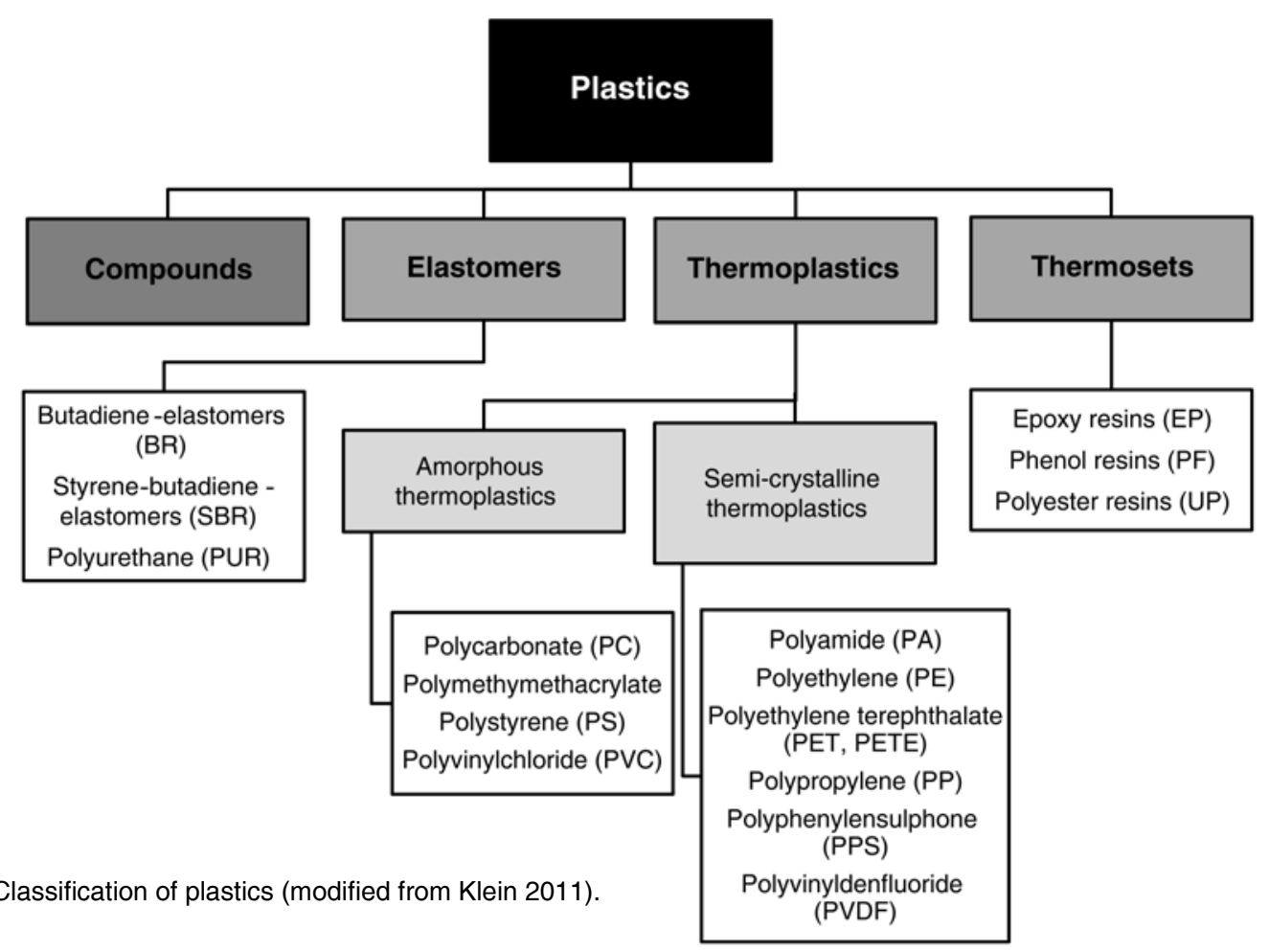

Figure 1 Classification of plastics (modified from Klein 2011). 
improve flexibility and durability (Till et al. 1982, Latini et al. 2004) and work by decreasing the polymer $T_{g}$, making the plastic softer. PVC polymers use almost $90 \%$ of plasticizers produced worldwide (Cadogan and Howick 2000).

Specific phthalates used in food packaging materials such as plastic wrappers on candies, cooked meats, and cheese (Castle et al. 1988) are diethyl phthalate (DEP), dimethyl phthalate (DMP), di-isobutyl phthalate (DiBP), di-n-butyl phthalate (DnBP), and di(2-ethylhexyl) phthalate (DEHP) (Fasano et al. 2012, Sendón et al. 2012). The Food and Drug Administration (FDA) restricts food use-approved plasticizers to $30 \%$ of the weight of food containers (US FDA 2013a). PVC is predominantly plasticized with DEHP. DEHP use is declining due to health concerns and governmental regulatory changes (EU 2011), and is being replaced with linear phthalates and

\begin{tabular}{|c|c|c|}
\hline $\begin{array}{l}\text { Resin } \\
\text { code }\end{array}$ & $\begin{array}{l}\text { Polymer } \\
\text { name }\end{array}$ & Uses \\
\hline PETE & $\begin{array}{l}\text { Polyethylene } \\
\text { terephthalate }\end{array}$ & $\begin{array}{l}\text { Drink/water and soda bottles, } \\
\text { juice boxes, liquor boxes, food } \\
\text { trays, condiment jars, plastic film, } \\
\text { microwavable packaging }\end{array}$ \\
\hline & $\begin{array}{l}\text { High-density } \\
\text { polyethylene }\end{array}$ & $\begin{array}{l}\text { Milk, juice, water jugs, detergent } \\
\text { bottles }\end{array}$ \\
\hline & & \\
\hline & $\begin{array}{l}\text { Polyvinyl } \\
\text { chloride }\end{array}$ & $\begin{array}{l}\text { Bottles for cooking oil, salad dressing, } \\
\text { mouthwash, and liquor. Plastic wrap, } \\
\text { "blister packs," plastic pipes }\end{array}$ \\
\hline & $\begin{array}{l}\text { Low-density } \\
\text { polyethylene }\end{array}$ & $\begin{array}{l}\text { Produce, frozen food, and bread bags, } \\
\text { trash bags, squeezable bottles }\end{array}$ \\
\hline LDPE & & \\
\hline PP & Polypropylene & $\begin{array}{l}\text { Condiment and medicine bottles, } \\
\text { drinking straws, yogurt containers, } \\
\text { margarine tubs }\end{array}$ \\
\hline PS & Polystyrene & $\begin{array}{l}\text { Egg cartons, disposable plastic } \\
\text { tableware (cups, plates, cutlery), } \\
\text { packaging foam/“peanuts," "clamshell } \\
\text { packaging," food carryout containers }\end{array}$ \\
\hline Other & $\begin{array}{l}\text { Other } \\
\text { (includes } \\
\text { polycarbonate) }\end{array}$ & $\begin{array}{l}\text { Injection molded drinking bottles, } \\
\text { glasses, and food containers }\end{array}$ \\
\hline
\end{tabular}

non-phthalate plasticizers such as polyester (US DHHS 2011). DEHP is classified by the Environmental Protection Agency (EPA) as a class B2 probable human carcinogen that acts as an endocrine disruptor in the body (Zhou et al. 2011). Human exposure to DEHP is primarily through ingestion, exposure to DMP and DEP is through inhalation, and DBP and DEP can be absorbed transdermally (Guo et al. 2012).

Unlike some plasticizers, phthalates do not bind chemically to plastic products, and therefore can leach into foodstuffs (Zhou et al. 2011). Most guidelines are set for drinking water, but not all phthalates used in food packaging are addressed. The EPA limits phthalates according to the Phthalates Action Plan due to their toxicity to humans and terrestrial and aquatic animals (Russo et al. 2012, US EPA 2012). DEHP (CAS 117-81-7) is one of the most commonly used phthalates and is regulated under the EPA's Safe Drinking Water Act at a maximum contamination limit of $0.0056 \mathrm{mg} / \mathrm{L}$ (US EPA 2017a). The solubility of DEHP in water is low $(45 \mu \mathrm{g} / \mathrm{L})$, although DEHP may form colloidal dispersions with higher solubility values $(>285 \mu \mathrm{g} / \mathrm{L}$ ) (IPCS 1992). Phthalates migrate into ethanol more readily than water (Karačonji et al. 2017) because they are miscible with most common organic solvents (IPCS 1992). The migration of phthalates is likely influenced by $\mathrm{pH}$. Soft drinks at $\mathrm{pH} 3$ had five to 40 times more migration from plastic to liquid than $\mathrm{pH} 5$ mineral water (Bošnir et al. 2007). Given wine ethanol content (7 to $14 \% \mathrm{v} / \mathrm{v}$ ) and $\mathrm{pH}$ ( 3 to 4 ), it may be possible for more migration to occur into wine when compared to water (Amerine et al. 1980), though no data are available. While few studies have investigated the migration of plastic materials into wine, there have been studies that evaluate food contact materials (FCM) migration into food simulants (US FDA 1977a, Paseiro-Cerrato et al. 2017), fruit juices (De Quirós et al. 2015), mineral water, and soft drinks (Bošnir et al. 2007). After 30 days of exposure in PET bottles, DMP was not detected in mineral water, but was abundant in soft drinks, varying with preservative concentrations (sodium benzoate and potassium sorbate). DMP ranged from 18 to $2666 \mu \mathrm{g} / \mathrm{L}$ in soft drinks. However, this study did not determine whether the products were contaminated prior to being in bottle, such as through

\begin{tabular}{|c|c|c|c|c|c|c|}
\hline $\begin{array}{l}\text { Chemical class/ } \\
\text { compound }\end{array}$ & Abbrev. & $\begin{array}{c}\text { CAS } \\
\text { number }\end{array}$ & Formula & $\begin{array}{c}\text { Selected ion } \\
\text { monitoring }\end{array}$ & $\begin{array}{l}\text { Molecular } \\
\text { weight }\end{array}$ & Limits \\
\hline \multicolumn{7}{|l|}{ Phthalate } \\
\hline Dimethyl phthalate & DMP & $131-11-3$ & $\mathrm{C}_{10} \mathrm{H}_{10} \mathrm{O}_{4}$ & $163^{a}$ & 194 & \\
\hline Diethyl phthalate & DEP & $84-66-2$ & $\mathrm{C}_{12} \mathrm{H}_{14} \mathrm{O}_{4}$ & $149-177^{a}$ & 222 & \\
\hline$n$-Dibutyl phthalate & DBP & $84-74-2$ & $\mathrm{C}_{16} \mathrm{H}_{22} \mathrm{O}_{4}$ & $149-205^{a}$ & 278 & \\
\hline Butyl cyclohexyl phthalate & BcEP & $84-64-0$ & $\mathrm{C}_{18} \mathrm{H}_{24} \mathrm{O}_{4}$ & $149-223^{a}$ & 304 & \\
\hline Butyl benzyl phthalate & BBP & $85-68-7$ & $\mathrm{C}_{19} \mathrm{H}_{20} \mathrm{O}_{4}$ & $149-206^{a}$ & 312 & \\
\hline Bis-(2-ethylhexyl) phthalate & DEHP & $117-81-7$ & $\mathrm{C}_{24} \mathrm{H}_{38} \mathrm{O}_{4}$ & $149-167^{a}$ & 390 & $0.006 \mathrm{mg} / \mathrm{L}^{\mathrm{b}, \mathrm{c}}$ \\
\hline \multicolumn{7}{|l|}{ Bisphenol } \\
\hline Bisphenol A & BPA & $80-05-7$ & $\mathrm{C}_{15} \mathrm{H}_{16} \mathrm{O}_{2}$ & $\begin{array}{l}(213.10,228.10,119.05 \\
216.10,234.10,121.05)^{d}\end{array}$ & 228 & $0.05 \mathrm{mg} / \mathrm{kg}-\mathrm{day}^{\mathrm{e}, \mathrm{f}}$ \\
\hline Bisphenol F & BPF & $620-92-8$ & $\mathrm{C}_{13} \mathrm{H}_{12} \mathrm{O}_{2}$ & & 200 & \\
\hline Bisphenol S & BPS & $80-09-1$ & $\mathrm{C}_{12} \mathrm{H}_{10} \mathrm{O}_{4} \mathrm{~S}$ & & 250 & \\
\hline
\end{tabular}

aRusso et al. 2012, bUS EPA 2009, ' US FDA 2013b, dMacek and Burkhardt 2011, eUS EPA 1993, and fEU 2008. 
exposure in the bottling line. If the source of contamination was the bottling line, a similar conclusion might be made for the bottling of wine.

Regulatory intake, defined as tolerable daily intake (TDI), is not defined clearly across states, countries, or globally, and differs for each type of plasticizer. Ideally, suggested TDIs should account for gender, age, duration of exposure, and body mass. The TDI set by the EPA for nine phthalates ranges from 0.02 to $0.8 \mathrm{mg} / \mathrm{kg} /$ day orally. The European Food Safety Authority's (EFSA) TDI for phthalates is $0.01 \mathrm{mg} / \mathrm{kg} /$ day for DBP, $0.05 \mathrm{mg} / \mathrm{kg} /$ day for BBP, and $0.05 \mathrm{mg} / \mathrm{kg} / \mathrm{day}$ for DEHP (Moreira et al. 2013). The US Consumer Product Safety Commission examined target subpopulations (women, infants, toddlers, and children), and for eight phthalates (DEP, DBP, DIBP, BBP, DNOP, DEHP, DINP, and DIDP) found that ingestion of food, beverages, and drugs were the greatest sources of phthalate exposure, rather than children's toys and personal care products (Gennings et al. 2014). Estimated means of phthalate exposure ranged from 0.00015 to $0.0308 \mathrm{mg} / \mathrm{kg} / \mathrm{day}$. The EPA's reference doses for phthalates include $0.8 \mathrm{mg} / \mathrm{kg} /$ day for DEP, $0.1 \mathrm{mg} / \mathrm{kg} /$ day for DBP, $0.02 \mathrm{mg} / \mathrm{kg} /$ day for DEHP, and $0.2 \mathrm{mg} / \mathrm{kg} /$ day for BBP (US EPA 2017b, 2017c, 2017d, 2017e). TDI limitations may not consider the isomeric mixtures of phthalates, with some studies only focusing on a few of the hundred potential isomers with varying physiological impact. Additionally confounding is the fact that few epidemiological studies have been conducted on humans. Though correlations between toxicity data on animal subjects can be made with human health, more work is needed to understand the physiological impacts on human health. The FDA's guidance for packaging, or food contact substances (FCS), indicates a consumption factor (CF) for the fraction of content within a daily diet of a particular additive. The $\mathrm{CF}$ of plasticized linear low-density polyethylene (LLDPE) is $0.05 \mathrm{mg} / \mathrm{kg}$, under the assumption that migration is occurring in alcoholic beverages with alcohol concentrations ranging from 10 to $15 \%(\mathrm{v} / \mathrm{v})$ ethanol/water, with no specific regulation applied to wine containers (US FDA 2007a). Despite the lack of global regulatory limits and study limitations, compelling evidence suggests a link between phthalates and negative effects on reproductive, fetal developmental, liver, kidney, heart, lung, and hematologic health in humans (DiGangi et al. 2002), illustrating the need for HACCP systems when phthalate-containing plastics are used in food storage products.

Bisphenols. Bisphenols are primary constitutional monomers used in production of epoxy resins and polycarbonates used in food contact materials (FCM) applications (Table 2). Epoxies are used to line canned food containers, processing pipes, and concrete wine tanks, among many other uses (Pivnenko et al. 2015). Epoxy resins are produced through the reaction of epichlorohydrin and bisphenol A (BPA) to form bisphenol A diglycidyl ether (DGEBA or BADGE). Epoxy resins may be further reacted (cured) through catalytic homopolymerization or by forming a copolymer with hardeners or curatives to form thermosetting, cross-linked polymers that exhibit strong mechanical properties with high temperature and chemical resistance. Hardeners include phenols, anhy- drides, polyfunctional amines, and thiols, in order of increasing reactivity.

Polycarbonate polymers are commonly used in water bottles and food storage containers because they are durable, with high impact-resistance, temperature resistance, and optical clarity. Since the 1950s, BPA has been used as the monomer in polycarbonate plastic, resulting in global production estimated at 10 billion pounds per year (vom Saal et al. 2012). BPA was approved by the FDA for products containing food in the 1960s (Grignard et al. 2012). Polycarbonate is typically produced by reacting BPA and phosgene $\mathrm{COCl}_{2}$, but may be produced from other bisphenols like bisphenol $\mathrm{S}$ (BPS) or bisphenol F (BPF) (Table 2). BPA may be used as an antioxidant for polymer and plasticizer use in PVC production (Grossman 2008). Leaching of BPA occurs when the molecules are hydrolyzed from polycarbonate as temperature increases at high or low pH (Fasano et al. 2012), although BPA is poorly soluble in water (Le et al. 2008). When BPA-containing plastics or epoxy-lined storage containers are scratched or damaged over time, BPA can leach into food and beverages (Brotons et al. 1995, Brede et al. 2003, Howdeshell et al. 2003). Wine storage bags are often made of polycarbonate plastic (also called \#7), which contain BPA.

BPA has received considerable attention as a suspected toxicant due to its weak estrogenic activity, which is suggested to disrupt endocrine and estrogen signaling, alter human development, and cause breast and prostate cancers; this has led to usage restriction (Timms et al. 2005, Matsushima et al. 2007, Barrett 2008, Grignard et al. 2012). Nevertheless, migration of BPA into foods from packaging materials occurs at very low concentrations (Ackerman et al. 2010, Noonan et al. 2011). Few data are available on bisphenol migration into wine, though BPA and its curing agent methylenedianiline migrated through epoxy resin vats into model wine at concentrations of up to 30 and $7.6 \mathrm{mg} / \mathrm{kg}$ resin, respectively (Larroque et al. 1988). New research would be needed to determine whether contemporary tanks exhibit similar migration. BPA from plastic food containers is not expected to be a risk to consumers (Bang et al. 2012). US FDA and EFSA both agree that BPA poses no health risk to any age group under normal dietary exposures consumed, with women of childbearing age and men of comparable ages experiencing an exposure of up to $0.388 \mu \mathrm{g} / \mathrm{kg} / \mathrm{day}$, well below the recommended TDI of $4 \mu \mathrm{g} / \mathrm{kg} / \mathrm{day}$. (US FDA 2014, EFSA 2015). No United States regulatory agency restricts levels of BPA in food; however, 12 states have policies to limit BPA exposure (Safer States 2017). For example, in 2015, California listed BPA on its Proposition 65 list, also known as the Safe Drinking Water and Toxic Enforcement Act of 1986, which prohibits companies and individuals from using chemicals known to the state to cause cancer or reproductive toxicity (OEHHA 2015, Misko 2016). As a result, many manufacturers are developing new formulations of non-BPA-containing epoxies and other alternatives.

While many manufacturers have discontinued the use of BPA or alternatively use BPA non-intent (BPA-NI) alternatives (BPA-NI means that no BPA was intentionally added), 
cross-contamination of trace amounts of BPA may be possible during the manufacturing process and contact with material still containing BPA that may be used on shared equipment. Additionally, they may instead be using BPS or BPF that also test positive for estrogenic activity (Molina-Molina et al. 2013, Gander 2016). Two highly standardized transactivation assays found the estrogenic activity of BPA and BPS concentrations to be comparable (Grignard et al. 2012).

Several winemaking materials have been tested for the presence of BPA, including wine stoppers; wine storage vats made of steel, wood, and plastic; glass bottles; Tetra Briks (mean concentration $0.58 \mathrm{ng} / \mathrm{mL}$ ) (Brenn-Struckhofova and Cichna-Markl 2006); and in an unspecified brand of synthetic corks (Zapel 2011). A small sample of beer and soda cans reportedly contained 1.7 to $3.5 \mu \mathrm{g}$ BPA per can, attributed to the epoxy lining (Müller 2017). Ester bonds linking BPA to polycarbonate and epoxy resins of food storage material are hydrolyzed when exposed to heat and contact with acidic or basic foods, which releases bisphenols into foods (Fasano et al. 2012).

NIAS may also be an issue, especially where new, alternative polymers are used which, despite FDA guidance documents, may not be fully understood (US FDA 2007b, Paseiro-Cerrato et al. 2017). The FDA regulates food-contact "resinous and polymeric coatings," listing approved precursor materials and setting migration limits of total extractives from the coating to the food (US FDA 1977b).

\section{Hazard Analysis Critical Control Points (HACCP)}

As plastics use increases in wineries, little is known about the implications of plastic-containing products on identified critical control points (CCP) and safety programs. To monitor the safety of food products, including their packaging, HACCP are used by food producers, regulatory authorities, and inspection services (Bovee et al. 1997), and increasingly, with winemaking. For example, the European Union set maximum concentration limits for ochratoxin A (OTA), a fungus-derived toxin in wines, for all member states, and HACCP have been proposed as a method to address that risk (Martínez-Rodríguez and Carrascosa 2009), which may also be applicable to plastic additive contamination. Though HACCP in wineries have not been required under the US Food Safety Modernization Act (FSMA) (Leake 2014), the FSMA has required FDA inspection of wineries since 2018. FSMA will be used to monitor the whole food production chain, so in addition to wineries, custom-crush operations and mobile bottling operations will be considered (Smith 2013). Several control points (CPs) and CCP lists and guides have been published in journal articles and through universities, and are available for use in wineries. While CPs are important, CCPs are crucial for product quality and manufacturing safety. CPs and CCPs can be used to develop Wine Standards Management Plans (WSMP) in a winery (NZ FSA 2017). CPs and CCPs occur in the vineyard, in transport of fruit from vineyard to winery, and in the winery. CPs and CCPs for grapes, must, and wine are related to physical, chemical, and microbial hazards, and to quality parameters such as product appearance, consumer acceptability, flavor, color, and aroma. Good manufacturing practices and vineyard management are key to maintaining CPs and CCPs (Christaki and Tzia 2002). In the United States, wineries must have a permit with the Alcohol and Tobacco Tax and Trade Bureau (TTB) and be registered with the FDA under the Bioterrorism Act of 2002. Wine is considered low in risk of food safety hazards according to the TTB and FDA. However, the FSMA imposes a few additional safety factors, such as enforcing continued registration with government agencies, recalls, product detainment, and import regulation (Smith 2013). One important consideration that is overlooked in CPs and CCPs is plastic usage. Plastic is either not mentioned or is not considered a biological, chemical, or physical hazard (NZ FSA 2017). However, based on research from other foods and beverages, and the lack of published data on wines, there may be a need to re-evaluate and research potential hazards of plastics in winemaking.

Regardless of the scientific or regulatory consensus about health risks, they may be irrelevant to market forces from negative public perception and the assumption that plastics are a hazard in a wine industry that increasingly uses plastics. For example, part of a "Chemical Fallout" article series by the Milwaukee Journal Sentinel outlined negative effects of BPA, to much praise (Rust et al. 2007). A study of public response to this controversy across news media determined that despite mixed opinions in the scientific community as to the confirmed link between risks and consumption, most people who had been exposed to even a small amount of information about BPA were concerned and favored a ban on its use (Brewer and Ley 2011). As outlined in Brewer and Ley (2011), three main actors were involved in perception of BPA, which could also be expanded to other compounds like phthalates: science, business, and government. Irrespective of health effects or lack thereof, and so even for benign compounds, negative marketing or public perception may have grievous consequences. While implementation of HACCP practices may help mitigate health risks and satisfy regulatory requirements, we suggest that HACCP approaches may also be beneficial if applied to other areas, such as hazard analysis of CCPs in wine production processes that may influence public perception and marketing, in addition to effects on wine flavor and quality.

Plastics and plastic additives in wine. Plasticizers tend to be lipophilic, with limited solubility in aqueous alcohol solutions. However, many foodstuffs used to make alcohol (grapes, apples, grains, etc.) have some lipophilic substances in their skins that may accumulate plasticizers through contact (Fuller et al. 2011). From the time they are picked, fruit used to make wine may contact plastics that potentially contain plastic additives. For example, fresh-picked plums transported in plastic bags had detectable levels of DEP, DBP, and DIBP (Jurica et al. 2016). After entry into the winery, fruit and wine ingredients may be exposed to pumps, tubing, transport containers, pneumatic press material, additives such as flavorings, storage tanks, bulk shipping containers, 
and consumer packaging materials that can all contain or be contaminated with plasticizers or bisphenols, and possibly contribute cumulative amounts of these chemicals to the wine (Del Carlo et al. 2008, Buglass 2010, Sendón et al. 2012). Even though the fruit, must, and wine residence time with any one of these plastics-containing materials may be short, the cumulative exposure potential for leaching is unknown and worthy of additional research.

Plasticizers have been quantified in alcoholic beverages other than wine, such as Chinese baijiu, a white spirit distilled from a variety of grains such as sorghum, rice, wheat, or corn. An average level of $0.537 \mathrm{mg} / \mathrm{kg}$ of plasticizers was found across a wide variety of Chinese liquors (Yinan 2012) with some containing more than three times the amount of DBP compared to the standard set in 2011 by the Ministry of Health (China.org 2012, Zhu 2012). Greater quantities of DBP and DIBP were found in wine and beer compared to other beverages, with more than $94 \%$ of food samples containing these two plasticizers (Guo et al. 2012). Other grain-neutral spirits and vodka contained phthalate plasticizers including
DBP, DOP, and DEHP; however, they were considered biologically insignificant (Leibowitz et al. 1995).

Plastics are used throughout the winemaking process, including transport and storage of wine (Table 3). Just as in liquor manufacturing, various stages in winemaking may involve plastic products that contain leachable plasticizers and other additives. Wine may come into contact with extractible plasticizers such as DBP and DEHP, the most common phthalate contaminants in wine (Buglass 2010). In some cases, plastics are used because they offer advantages to traditional packaging. For example, PET bottles and Bag-in-Box containers weigh less than a glass wine bottle of the same volume and do not shatter, so shipping costs are lower and storage is easier (Scheer and Moss 2012). Several of these features are considered environmentally friendly. Packaging used for boxed wine has some advantages because it prevents oxidation longer than glass bottles after opening and can keep wine fresh for up to six weeks after opening (Ghidossi et al. 2012). A drawback of using plastic is the potential for plastic materials in contact with wine to scalp volatile

\begin{tabular}{|c|c|c|}
\hline Activity type/item & Material & Potential additive \\
\hline \multicolumn{3}{|l|}{ Transport } \\
\hline \multicolumn{3}{|l|}{ Container } \\
\hline Flexible transport tank & PE, PP, polyester, PVC & DBP, DEP, DEHP, DMPa, BPA \\
\hline $\begin{array}{l}\text { Intermediate bulk containers (IBCs), } \\
\text { drums, totes, and bins }\end{array}$ & PE, HDEP, PP & DBP, DEP, DEHP, DMPa \\
\hline \multicolumn{3}{|l|}{ Equipment } \\
\hline \multicolumn{3}{|l|}{ Crush } \\
\hline Press bladder membrane & Nylon, rubber, polyester, PVC, silicone & $?$ \\
\hline Conveyor belts & Nylon, rubber, polyester, PVC, silicone & $?$ \\
\hline \multicolumn{3}{|l|}{ Pumps \& hoses } \\
\hline Seals, impellers, bearings, lines, hoses & PE, polyacetal, PVC & DBP, DEP, DEHP, DMPa, BPA \\
\hline \multicolumn{3}{|l|}{ Tanks/containers/barrels } \\
\hline Poly tanks & PE & DEHA, DBP, DEHP \\
\hline Fiberglass tanks & Fiberglass-epoxy/PVC & BPA \\
\hline Concrete & May be lined with epoxy ${ }^{c}$ which may contain $P V C^{d, e, f}$ & BPA \\
\hline \multicolumn{3}{|l|}{ Ingredients/fining/resins } \\
\hline \multicolumn{3}{|l|}{ Filtration } \\
\hline \multicolumn{3}{|l|}{ Media \& housings } \\
\hline Pads and resins & $?$ & $?$ \\
\hline Reverse osmosis membranes & $\mathrm{PP}$, nylon, polyethersulfone, silicone elastomer ${ }^{g, h}$ & DBS, DEP, DIBP \\
\hline Ultrafiltration media & $\mathrm{PP}$, nylon, polyethersulfone, silicone elastomer $\mathrm{r}^{\mathrm{g}, \mathrm{h}}$ & DBS, DEP, DIBP \\
\hline \multicolumn{3}{|l|}{ Packaging } \\
\hline \multicolumn{3}{|l|}{ Bottle stoppers } \\
\hline Synthetic "cork" & \#4 LDPE or \#7 mixed plastics & DBP, DEP, DEHP, DMP ${ }^{a, c}, D^{2} H A^{b}$ \\
\hline Agglomerate corks & PUR & DEHPi \\
\hline Natural cork coatings & Paraffin, waxes, silicon, other polymer coatings ${ }^{j}$ & $?$ \\
\hline Screwcap liners & \#4 LDPE, PVC, PVDC & DBP, DEP, DEHA; DEHP, DMP a,b,k \\
\hline \multicolumn{3}{|l|}{ Containers } \\
\hline Bag-in-Box & $\mathrm{PE}, \# 7$ mixed plastics/PC & DBP, DEP, DEHP, DMPa BPA $^{d}$ \\
\hline PET bottles & PET & DBP, DEP, DEHP, DMPa \\
\hline Aluminum can lining & Epoxy/PVC, \#7 mixed plastics ${ }^{\mathrm{d}} / \mathrm{PC}^{\mathrm{l}}$ & BPA \\
\hline
\end{tabular}

${ }^{a}$ Fuller et al. 2011, bGroth and Silbergeld 1998, 'Zapel 2011, dScheer and Moss 2012, e Sheftel 2000, 'Teichgraeber 2005, gPall Corp., h3M 2011, iSix and Feigenbaum 2003, 'Amerine and Joslyn 1970, kNara et al. 2009, 'Natural Resources Defense Council 2011. 
flavors from wine, or wine may absorb undesirable aromas from plastic (Peyches-Bach et al. 2012). Examples of plastic materials that may contact wine are stoppers, including those used to seal partially-consumed bottles of wine, and aluminum cans and concrete fermenters, which were commonly lined with BPA-based epoxy, although BPA-NI alternatives are available (Sheftel 2000, Teichgraeber 2005, Scheer and Moss 2012, Gander 2016). Wine-in-can consumer acceptance and sales share are increasing and are areas of great interest and concern for manufacturers (Johnston and Velikova 2016, O’Donnell 2016).

Alternatives to natural bark cork closures are also a concern for plasticizer contamination. Alternative closure use such as synthetic corks and screwcaps are becoming more common due to the rate of cork taint, estimated at 3 to $5 \%$ of bottled wine, caused by 2,4,6-trichloroanisole (TCA) that imparts musty, wet-cardboard aromas (Butzke and Suprenant 1998, Jennings 2012). Synthetic closures comprise an estimated $19 \%$ of the closure market, of which $11 \%$ are metal screwcaps, out of $\sim 20$ billion wine bottles per year (Steeman 2010). A greater range of plasticizers occurs in plastic closures than in other plasticized plastic materials used in winemaking (Buglass 2010, Sendón et al. 2012). SARANEX is a barrier film used in both screwcap liners and synthetic closures and consists of layers of SARAN resin (polyvinylidene chloride, PVDC) and thermoplastic polymer resins (Dow 2013). SARAN resin contains PVC, a source of plasticizer contamination. Di(2ethylhexyl)adipate (DEHA) and phthalates such as DBP and DEHP are plasticizers found in PVC-based films (Groth and Silbergeld 1998). LDPE has been used to replace PVC in SARAN (https://www.whatsinsidescjohnson.com/en-us/productsby-brand/saran/saran-premium-wrap.aspx; accessed 14 March 2014); however, it can scalp flavor and aroma compounds and provides a poor oxygen barrier (Smith and Hui 2004). In addition, use of artificial closures, plastic liners in screwcaps, and other plastic closures may expose wine to plastic leachates that alter organoleptic properties in the wine, as with other foods and beverages (Wagner and Oehlmann 2009).

In the environment, apart from a few fungal species and bacterial isolates, it is difficult for plastics to be broken down by microbes because they lack the enzymes necessary to convert biochemically novel compounds such as plastic molecules into intermediates (Yoshida et al. 2016). Nevertheless, certain microbes are integral in the process of winemaking, and although no known wine-associated microbes can break down plastics, more work is needed to determine whether microorganisms in wine promote breakdown of plastics involved in wine processing, storage, and packaging, and with what human health or wine quality consequences. It is also important to identify wine microorganisms potentially capable of degrading bio-based plastics. Microbes can degrade organic and inorganic compounds such as lignin, starch, cellulose, and hemicellulose, so storage in bio-based plastic containers should be examined.

Exposure considerations. Concentrations consumed by humans depend on many variables: storage conditions, chemical properties of the beverage, and packaging type influence the amount of leaching, while intake, gender, size, and age of the person all affect the biological consequences of consumption. Moderate drinkers of alcoholic beverages are described as individuals who consume no more than four drinks for men and three drinks for women in a single day, and a maximum of 14 drinks for men and seven drinks for women per week (Nordqvist 2018). In comparison to the estimated BPA consumed based on the National Health and Nutrition Examination Surveys, total adult intake ranged from 30 to $70 \mathrm{ng} / \mathrm{kg} /$ day between 2005 and 2010, and was mainly attributed to canned food consumption (Lorber et al. 2015). Estimated exposure of seven phthalate monoesters, as measured by urinary metabolites, ranged from 1.7 to $110 \mathrm{mg} /$ $\mathrm{kg} /$ day for the $95^{\text {th }}$ percentile of the population. Phthalates were based on total exposure, including consumption, absorption through skin, and inhalation (Kohn et al. 2000). For an adult man with an average weight of $89.6 \mathrm{~kg}$ (Gill 2018) who drinks four standard 148-mL glasses of wine (https://www. niaaa.nih.gov/alcohol-health/overview-alcohol-consumption/ what-standard-drink; accessed 2 May 2018) per day with a potential BPA concentration of $0.58 \mathrm{ng} / \mathrm{L}$, his exposure to BPA from this consumption is $343.36 \mathrm{ng}$, or $3.8 \mathrm{ng} / \mathrm{kg} / \mathrm{day}$, a tenth of the lowest total adult daily intake. Though many factors affect the concentrations of plastic additives in wine (e.g., storage conditions, manufacturing process), the average amount of BPA in wine from the papers reported in this review was $0.58 \mathrm{ng} / \mathrm{mL}$ (Lambert and Larroque 1997, BrennStruckhofova and Cichna-Markl 2006). Different phthalates are examined and reported in each study, but total phthalates in wines ranged from 0.0027 to $0.015 \mathrm{mg} / \mathrm{L}$ (Carrillo et al. 2008). The same man consuming four drinks at the high end of the range cited in this last study would consume $0.0089 \mathrm{mg}$ of phthalates, much lower than the previously discussed $95^{\text {th }}$ percentile of consumption (Kohn et al. 2000). Just as alcohol affects each age, gender, and size of person differently, each person's ultimate exposure to additives may differ based on the same variables. Finally, it begs the question: how much of these plastic additives must a person consume before they experience health problems, if at all?

\section{Analytical Methods}

Due to the widespread use of bisphenols and phthalates, disposable laboratory plasticware such as pipette tips may be contaminated with or contain these additives, which can compromise laboratory experiments (Del Carlo et al. 2008). For example, oleamide and biocide leachate from laboratory PP disposable laboratory plasticware affect protein function in biological research (McDonald et al. 2008). Laboratories can pursue manufacturers that disclose information on the additives used to manufacture their plastic products to determine if potential leachates might compromise the validity of their research results. Regardless, researchers may still need to confirm the absence of effects due to additive contamination or to account for them in their assay methods and results.

A pre-concentration step is necessary prior to the detection of bisphenols and phthalates because they are mostly found 
at trace levels ( $\mathrm{ng} / \mathrm{mL}$ or less). Examples of concentration methods include liquid-liquid extraction (LLE) (Del Carlo et al. 2008), solid-phase extraction (SPE) (Del Carlo et al. 2008, Russo et al. 2012), multi-walled carbon nanotuble sorbents ( $\mathrm{Li}$ et al. 2013), solid-phase micro-extraction (SPME) (Carrillo et al. 2007, 2008), and stir-bar sorptive extraction (SBSE) (Pfannkoch and Whitecavage 2002).

Determination of phthalates. Several analytical methods have been used to determine phthalate concentration in various materials used in making and storing wine, however, detection of phthalates is challenging because of their ubiquitous nature in the laboratory environment (Del Carlo et al. 2008). Eliminating background traces of phthalates is important in order to report accurate limits of detection (Bradley et al. 2013). Phthalate analysis is based mainly on gas chromatography-flame ionization detection (GC-FID) and gas chromatography-mass spectrometry (GC-MS); however, gas chromatography/ion trap-mass spectrometry (GC/IT-MS), high performance liquid chromatography-ultraviolet visible detection, and liquid chromatography-mass spectrometry (LC-MS) are also used (Cao 2010, Russo et al. 2012). DBP, $\mathrm{BBP}$, and DOP have been detected in wines, with DEHP at levels exceeding the EPA limit $(0.0056 \mathrm{mg} / \mathrm{L}$ in water). Of particular concern is the detection of phthalates from plastic based stoppers made from synthetic or agglomerated cork (Carrillo et al. 2008, Sendón et al. 2012).

$G C$-FID. GC-FID has been used primarily to examine other foods, not alcoholic beverages. However, GC-FID was used to establish the efficacy of single-drop microextraction (Batlle and Nerín 2004). Three aqueous food simulants containing trace phthalates were analyzed, including $15 \%(\mathrm{v} / \mathrm{v})$ ethanol/water, $3 \%(\mathrm{w} / \mathrm{v})$ acetic acid/water, and distilled water. In comparison to SPME, recovery was effective, ranging from 85 to $115 \%$ for most compounds. Limits of detection (LOD) were below those recommended by the EPA.

$G C-M S$. Solid-phase extraction-gas chromatography-mass spectrometry (SPE-GC-MS) was used to determine the low, trace concentrations of six phthalate esters in red and white wines from commercial sources, private producers, and experimental lots (Del Carlo et al. 2008). All wine samples were contaminated with phthalates. The LOD for the analysis was $18 \mathrm{ug} / \mathrm{L}$, and the limit of quantitation (LOQ), $29 \mathrm{ug} / \mathrm{L}$. In comparison to current TDI amounts, which are specified based on $\mathrm{mg} / \mathrm{kg} / \mathrm{day}$, the amount consumed and factors such as gender and age determine whether an individual is exposed to safe amounts.

Plastic wine tops were held under "extreme conditions" (EC) of incubation in an oven at $40^{\circ} \mathrm{C}$ for 10 days or in an ultrasonic bath for $15 \mathrm{~min}$ and exposed to $15 \%(\mathrm{v} / \mathrm{v})$ ethanol/ water (Fasano et al. 2012). Eight compounds were examined with SPE-GC-MS, four of which were phthalates, and it was determined that all plastic wine tops receiving EC treatment were contaminated by all phthalates, and those given the ultrasonic treatment were contaminated with two to three phthalates.

The best fibers for examining phthalate esters in wine were polyacrylate, carbowax-divinylbenzene, and polydimethyl- siloxane-divinylbenzene (Carillo et al. 2007). Further work using isotopically-labelled phthalate internal standards with HS-SPME-GC-MS determined that total phthalates in the wines analyzed ranged between 0.0027 and $0.015 \mathrm{mg} / \mathrm{L}$ (Carrillo et al. 2008).

Electron spin resonance. Migration of DOXYL and TEMPO-phthalate probes from agglomerated champagne cork stoppers was examined using electron spin resonance (ESR) (Six et al. 2002, Six and Feigenbaum 2003). Paramagnetic probes were incorporated into the adhesive and cork during processing. To incorporate the probes, cork granules were sealed with probes in a hermetic poll box in an oven held at $70^{\circ} \mathrm{C}$ for $2 \mathrm{hrs}$ for TEMPO-phthalate. Ten g cork granules was molded with $1.75 \mathrm{~g}$ adhesive plus $0.3 \mathrm{~g}$ Vaseline. Corks were immersed in alcoholic simulant of wine $(12 \% \mathrm{v} / \mathrm{v}$ ethanol/water at $\mathrm{pH} 3$ ) for 10 days at $40^{\circ} \mathrm{C}$. ESR spectra of cork slices indicated simulant wine penetrated the whole structure of the finished cork.

GC/IT-MS. Pre-concentration is necessary to develop sensitive analytical methods for trace compounds such as phthalates. The pre-concentration step to optimize SPE-GC/ IT-MS used Carbograph 1 sorbent to improve recovery of phthalate by 78 to $105 \%$ (Russo et al. 2012). The method was both sensitive and reproducible in the red and white wines analyzed.

Champagne corks were analyzed for potential migrants of concern: toluene diisocyanate and methylene bisphenylisocyanate in adhesives, lubricants, and surface treatments (Six and Feigenbaum 2003). Analysis was conducted spectroscopically and chromatographically. The composition was determined and verified by infrared spectroscopy, proton nuclear magnetic resonance spectroscopy (1H-NMR), and GC-MS. The presence of other solutes in wine, such as sugars, decreased migration of additives from cork. Thus, experiments using simulant wine can overestimate this migration, providing an extra margin of safety when compared to levels found in actual wine. DEHP was the only migrant detected from the corks, with $90 \%$ of extraction occurring within one day in all tests. DEHP was specifically monitored in further tests, which found transfer from cork to simulant wine to be 50 $\mu \mathrm{g} / \mathrm{L}$. Existing regulations on silicone elastomers in France were used as a reference value for safe levels of migration from champagne corks; therefore, migrated DEHP was less than the legal reference of $3 \mathrm{mg} / \mathrm{L}$.

Liquid chromatography. Agglomerated corks are made from natural cork granules and adhesives that contain esters such as phthalates and adipates. HPLC-MS/MS was used to examine the presence of phthalates in 21 agglomerated cork stoppers and their potential migration into $12 \%(\mathrm{v} / \mathrm{v})$ ethanol/ water, but no corks yielded quantifiable levels of phthalate migration (Sendón et al. 2012). HPLC was also used to determine the presence of phthalates in Korean and Japanese retail beverages, including alcoholic beverages such as the Japanese distilled beverage sho-chu, beer, rice punch, red wine, and white wine (Yano et al. 2002). Levels of DBP in Japanese red wines were among the highest sampled at $0.275 \mu \mathrm{g} / \mathrm{g}$ : nearly $100 \%$ greater than in Korean wine. LC-GC-MS is an efficient 
method to examine phthalate residues in grain neutral spirits and vodka (Leibowitz et al. 1995). Six reported phthalates were quantitated in 50 samples, although the detected concentrations of as little as $20 \mu \mathrm{g} / \mathrm{L}$ were insignificant compared to the suggested threshold for long-term exposure, $15 \mathrm{mg} / \mathrm{L}$. Most recently, an SPE-LC-MS method was used to determine four phthalates in water stored in plastic bottles and white and rosé wine stored in Tetra Brik packages (Barciela-Alonso et al. 2017). All four phthalates were found in water, though DEP and DBP were the only phthalates recovered in both types of wine.

Determination of bisphenols. Many solvent extraction methods and SPE are used to isolate BPA from samples, followed by analysis such as LC, GC, and immunochemical methods (Ballesteros-Gómez et al. 2009).

$S P E$ with GC-MS. Migration tests examined levels in 11 types of common food packaging materials, including plastic wine tops made with elastomers and foams (ethylene, propylene, urethane, silicones, or their copolymers with different additives) (Fasano et al. 2012). The migration test used liquid FCMs to simulate different types of foods: distilled water for aqueous foods with $\mathrm{pH}$ above $4.5,3 \%$ acetic acid in distilled water for acidic aqueous foods with $\mathrm{pH}$ below $4.5,15 \%$ ethanol for alcoholic foods, and oil for fatty foods. Migration test conditions were $40^{\circ} \mathrm{C}$ for 10 days, which was considered "ECs" (Fasano et al. 2012). Analytes were concentrated with SPE and quantified with GC-MS. Plastic wine bottle tops showed the highest level of migration for one of the two alkylphenols and for three of the four phthalates when compared to the 10 other sources of food packaging materials that included items such as baby food packaging, canned food, food bags, and glass jar caps. Of the three phthalates found, levels were 25 to 75 times greater than the greatest amount found in the other packaging materials. BPA was not recovered from wine bottle tops. The authors concluded risk due to exposure is primarily associated with potentially negative impacts on health. Where wine is stored on its side, there may be potential migration issues from wine bottle tops.

HPLC. HPLC with fluorescence detection was used in wine and mineral water, which can be contaminated through exposure to epoxy resins lining wine storage containers,

\begin{tabular}{|c|c|c|c|}
\hline Material & Name & Abbrev. & Sources \\
\hline Plastic & Cellulose acetate $^{a}$ & $\mathrm{CA}$ & Cotton fibers and wood \\
\hline Plastic & Cellulose acetate butyrate ${ }^{a}$ & CAB & Cotton fibers and wood \\
\hline Plastic & Cellulose acetate propionate ${ }^{a}$ & CAP & Cotton fibers and wood \\
\hline Plastic & Cellulose nano-composites ${ }^{b}$ & & $\begin{array}{l}\text { Obtained by chemical treatments and steam explosion of cellulose } \\
\text { materials }\end{array}$ \\
\hline Plastic & Corn zein ${ }^{a}$ & & Corn \\
\hline Plastic & Lignin $^{a}$ & & Plants and wood \\
\hline Plastic & Natural fiber reinforced composites ${ }^{a}$ & & Kenaf, hemp, ramie, flax, sisal, jute, pineapple leaf \\
\hline Plastic & Polyhydroxyalkanoate ${ }^{c}$ & PHA & Whey, lignocellulosic raw materials, molasses, glycerol, fats, wastewate \\
\hline Plastic & Polylactic acid ${ }^{a}$ & PLA & Corn, sugar beets, sugar cane, wheat, sweet potatoes, rice \\
\hline Plastic & Polysaccharide nanocomposites ${ }^{d}$ & & $\begin{array}{l}\text { Heparin, chitosan, cellulose, hyaluronan, starch, alginate, pectin, guar, } \\
\text { starch/chitosan, chitosan/heparin, chitosan/hyalurona, hyalurona/ } \\
\text { heparin, cellulose and chitin whiskers, platelet-like starch }\end{array}$ \\
\hline Plastic & Poly(trimethylene terephthalate) ${ }^{\mathrm{e}}$ & PTT & $\begin{array}{l}\text { Sugar from corn with terephthalic acid (PTA) or dimethyl terephthalate } \\
\text { (DMT) derived from petroleum }{ }^{\dagger}\end{array}$ \\
\hline Plastic & Soy protein ${ }^{a}$ & & Soybeans \\
\hline Plastic & $\begin{array}{l}\text { Starch derived plastics: } \\
\text { Thermoplastic starch }\end{array}$ & TPS & Corn, potato, rice, wheat, tapioca \\
\hline Plastic & Urethanes: polyol ${ }^{\mathrm{a}}$ & & Soy oil/soybean, castor oil, rapeseed, sunflower, linseed \\
\hline Plasticizer & Acetyl tributyl citrate & ATBC & Citric acid derivative \\
\hline Plasticizer & Acetyl triethyl citrate & ATEC & Citric acid derivative \\
\hline Plasticizer & Acetyl trihexyl citrate & ATHC & Citric acid derivative \\
\hline Plasticizer & Acetyl trioctyl citrate & ATOC & Citric acid derivative \\
\hline Plasticizer & Acetylated monoglycerides & & Edible fats and triacetin \\
\hline Plasticizer & Butylated hydroxytoluene & $\mathrm{BHT}$ & Phenol derivative \\
\hline Plasticizer & Butyl stearate & & Stearic acid and butyl alcohol \\
\hline Plasticizer & Butyryl trihexyl citrate & BTHC & Citric acid derivative \\
\hline Plasticizer & Epoxized soybean oil & ESBO & Soybeans \\
\hline Plasticizer & p-tert-Butyl phenyl salicylate & & 4-tertiary-butylphenol and salicylic acidg \\
\hline Plasticizer & Tributyl citrate & TBC & Citric acid derivative \\
\hline Plasticizer & Triethyl citrate & TEC & Citric acid derivative \\
\hline Plasticizer & Trihexyl citrate & THC & Citric acid derivative \\
\hline Plasticizer & Trioctyl citrate & TOC & Citric acid derivative \\
\hline
\end{tabular}

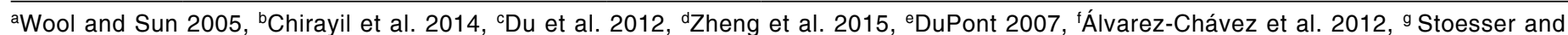
Sommerfield 1953. 
water towers, and drinking water pipes (Lambert and Larroque 1997). LODs ranged from 5 to $2.5 \mu \mathrm{g} / \mathrm{L}$ in red and white wine, and from 0.25 to $0.70 \mu \mathrm{g} / \mathrm{L}$ in mineral water. Sol-gel immunoaffinity, HPLC, and fluorescence detection were used to examine BPA contamination in wine exposed to vats (steel, wood, and plastic), glass bottles, and Tetra Brik type carton packages (Brenn-Struckhofova and Cichna-Markl 2006). Plastic wine stoppers were immersed in $11 \%$ ethanol and detectable levels of BPA were leached from the stoppers. Wine samples consisted of a total of 59 wines: 46 white and 13 red. In 13 samples, the BPA concentration was below the LOQ $(0.2 \mathrm{ng} / \mathrm{mL})$. Mean BPA for the wine samples was 0.58 $\mathrm{ng} / \mathrm{mL}$, below previously published BPA levels derived from migration experiments using wine simulants.

Alternative plastics and plasticizers: Bio-based options. Alternative plastics and plasticizers from natural compounds with no negative effect on human health and little to no impact on economic viability and product quality would likely be of interest to some producers in the wine industry, particularly those that desire to market more natural or organic winemaking approaches. Potential sources for natural plasticizers and bio-based polymers include polysaccharides, proteins, lipids, and microbes (Trela and Plank 2015). Bio-based compounds (Table 4) may decrease the need for petroleumbased plastics and plasticizers and reduce their toxicological and environmental impacts. Alternative plasticizers are an option to reduce toxicity due to plasticizer leachate in plastic products (Lowell Center for Sustainable Production 2011). Biopolymer films and natural-based plasticizers are less toxic and leachable, and more biodegradable than phthalate plasticizers, although tend to exhibit reduced mechanical properties and performance. Biopolymers are not widely represented in the market compared to less expensive non-biopolymer plastics, and currently only represent 5 to $10 \%$ of the market (Lowell Center for Sustainable Production 2011, Vieira et al. 2011). BPA-free and phthalate-free labels on many products make the public aware these substances are problematic, so bio-based alternatives may improve consumer confidence and perception.

Many food contact-approved plastic resins such as some formulations of PE currently offer useful functional properties and do not contain plastic additives (Dow 2014). LLDPE, HDPE, medium-density polyethylene, ultra-high-molecularweight polyethylene (UHMWPE), and cross-linked polyethylene (PEX) made with HDPE are generally considered plasticizer-free. PE wine bottle closures and wine tanks are options available to the wine industry. Phthalate-free alternatives to DEHP and DINP-containing plastic corks and cap liners may include low-volatility plasticizers such as Palatinol 10-P (Goth 2007) and those that are oil- and plasticizerfree (Elastocon 2015). Barrier films have also been applied to natural cork stoppers to prevent TCA-induced cork taint (Easton 2010). It is conceivable that barrier films may be developed that could prevent plasticizer leaching. It is worth mentioning that even PE products can contain bioactive ingredients added for various purposes (e.g., UV stabilization), but not necessarily in all instances or products.

\section{Conclusion}

HACCP are not required for wineries in the United States, however, additional benefits of developing a program include addressing health, wine quality, and public perception concerns regarding the use of plastics during winemaking. Manufacturers may state that a finished product does not contain certain additives such as bisphenols or phthalates, nevertheless, other additives may be present. Consumers and wine producers alike may not be aware that some plastics, such as PE, could contain additives synthesized from animal derived fatty acids (tallow) (Dow 2014). Therefore, labelling of these plastics may be warranted to satisfy situations in which individuals desire to comply with various religious dietary laws (e.g., kosher), or for personal reasons (e.g., vegan).

Concerned consumers and wine producers who use plastic may want to contact manufacturers for details, including resin codes and supporting Regulatory Data Sheet, about the plastic resins and additives used, notwithstanding nondisclosure of proprietary information. Independent lab tests may be needed for definitive details, however, results from independent lab tests can also be compromised due to ubiquitous use of plastic products in the laboratory (McDonald et al. 2008).

Consumers and wine producers concerned about leachate contamination can avoid potential sources of petroleum or animal-based chemicals by using traditional materials, such as wood, clay, stainless steel, glass, and cork. Additional action plans for winemakers specifically include developing CPs and CCPs for their winery that include identifying key points in which fruit, must, wine, and its ingredients are in contact with plastic-containing substances. For quality concerns, if plastic-containing items are used, conditions that encourage potential leaching and scalping should be avoided. If plastic is used in the final product, labelling to note any specific precautions taken (e.g., bisphenol-free) could be used to improve public perception. Identification of potential hazards through HACCP may improve product safety and quality and ultimately improve consumer confidence, marketability, and wine sales.

\section{Literature Cited}

3M. 2011. Wine Filtration Systems. 3M Purification Inc, Meriden, CT. http://multimedia.3m.com/mws/media/492758O/wine-filtrationbrochure.PDF.

Ackerman LK, Noonan GO, Heiserman WM, Roach JA, Limm W and Begley TH. 2010. Determination of bisphenol A in U.S. infant formulas: Updated methods and concentrations. J Agric Food Chem 58:2307-2313.

Álvarez-Chávez CR, Edwards S, Moure-Eraso R and Geiser K. 2012. Sustainability of bio-based plastics: General comparative analysis and recommendations for improvement. J Clean Prod 23:47-56.

Amerine MA and Joslyn MA. 1970. Table Wines: The Technology of Their Production. University of California Press, Berkeley, CA.

Amerine MA, Berg HW, Kunkee RE, Ough CS, Singleton VL and Webb AD. 1980. The Technology of Wine Making. AVI Publishing Company, Inc., Westport, CT.

ASTM International. 2013. ASTM D7611 / D7611M-13e1, Standard Practice for Coding Plastic Manufactured Articles for Resin Identification. ASTM International, West Conshohocken, PA. 
Ballesteros-Gómez A, Rubio S and Pérez-Bendito D. 2009. Analytical methods for the determination of bisphenol A in food. J Chromatogr A $1216: 449-469$.

Bang DY et al. 2012. Human risk assessment of endocrine-disrupting chemicals derived from plastic food containers. Compr Rev Food Sci F 11:453-470.

Barciela-Alonso MC, Otero-Lavandeira N and Bermejo-Barrera P. 2017. Solid phase extraction using molecular imprinted polymers for phthalate determination in water and wine samples by HPLC-ESI-MS. Microchem J 132:233-237.

Barrett K. 2008. Safety of Water Bottles, Baby Bottles Questioned. ABC News. https://abcnews.go.com/Health/story?id=4657968.

Batlle R and Nerín C. 2004. Application of single-drop microextraction to the determination of dialkyl phthalate esters in food simulants. J Chromatogr A 1045:29-35.

Bošnir J, Puntarić D, Galić A, Škes I, Dijanić T, Klarić M, Grgić M, Čurković M and Šmit Z. 2007. Migration of phthalates from plastic containers into soft drinks and mineral water. Food Technol Biotechnol 45:91-95.

Bovee EHG, de Kruijf N, Jetten J and Barendsz AW. 1997. HACCP approach to ensure the safety and quality of food packaging. Food Addit Contam 14:721-735.

Bradley EL, Burden RA, Leon I, Mortimer DN, Speck DR and Castle L. 2013. Determination of phthalate diesters in foods. Food Addit Contam Part A 30:722-734.

Brede C, Fjeldal P, Skjevrak I and Herikstad H. 2003. Increased migration levels of bisphenol A from polycarbonate baby bottles after dishwashing, boiling and brushing. Food Addit Contam 20:684-689.

Brenn-Struckhofova Z and Cichna-Markl M. 2006. Determination of bisphenol A in wine by sol-gel immunoaffinity chromatography, HPLC and fluorescence detection. Food Addit Contam 23:1227-1235.

Brewer PR and Ley BL. 2011. Multiple exposures: Scientific controversy, the media, and public responses to bisphenol A. Sci Commun 33:76-97.

Brotons JA, Olea-Serrano MF, Villalobos M, Pedraza V and Olea N. 1995. Xenoestrogens released from lacquer coatings in food cans. Environ Health Persp 103:608-612.

Butzke CE and Suprenant A. 1998. Cork Sensory Quality Control Manual. University of California, Division of Agriculture and Natural Resources, Publication Number 21571.

Cadogan DF and Howick CJ. 2000. Plasticizers. In Ullmann's Encyclopedia of Industrial Chemistry. Wiley-VCH Verlag $\mathrm{GmbH} \& \mathrm{Co}$. KGaA, Weinheim, Germany.

Cao XL. 2010. Phthalate esters in foods: Sources, occurrence, and analytical methods. Compr Rev Food Sci F 9:21-43.

Carrillo JD, Salazar C, Moreta C and Tena MT. 2007. Determination of phthalates in wine by headspace solid-phase microextraction followed by gas chromatography-mass spectrometry: Fibre comparison and selection. J Chromatogr A 1164:248-261.

Carrillo JD, Martínez MP and Tena MT. 2008. Determination of phthalates in wine by headspace solid-phase microextraction followed by gas chromatography-mass spectrometry: Use of deuterated phthalates as internal standards. J Chromatogr A 1181:125-130.

Castle L, Mercer AJ, Startin JR and Gilbert J. 1988. Migration from plasticized films into foods. 3. Migration of phthalate, sebacate, citrate and phosphate esters from films used for retail food packaging. Food Addit Contam 5:9-20.

Ceresana. 2011a. Market Study: Stabilizers (UC-2015). Ceresana, Constance, Germany. https://www.ceresana.com/en/market-studies/ chemicals/stabilizers/.

Ceresana. 2011b. Market Study: Pigments. Ceresana, Constance, Germany. https://www.ceresana.com/en/market-studies/chemicals/ pigments/.
Ceresana. 2011c. Market Study: Flame Retardants. Ceresana, Constance, Germany. https://www.ceresana.com/en/market-studies/chemicals/ flame-retardants/.

Ceresana. 2012. Market Study: Biocides. Ceresana, Constance, Germany. https://www.ceresana.com/en/market-studies/chemicals/biocides/.

Ceresana. 2013. Market Study: Antioxidants (UC-5005). Ceresana, Constance, Germany. https://www.ceresana.com/en/market-studies/ chemicals/antioxidants/.

China.org. 2012. Chinese alcohol maker apologizes for contamination. http://www.china.org.cn/china/2012-11/22/content_27200395.htm.

Chirayil CJ, Mathew L and Thomas S. 2014. Review of recent research in nano cellulose preparation from different lignocellulosic fibers. Rev Adv Mater Sci 37:20-28.

Christaki T and Tzia C. 2002. Quality and safety assurance in winemaking. Food Control 13:503-517.

D20 Committee. 2010. ASTM D7611/D7611M-10: Standard Practice for Coding Plastic Manufactured Articles for Resin Identification. ASTM International, West Conshohocken, PA. http://www.astm.org/ DATABASE.CART/HISTORICAL/D7611D7611M-10.htm.

Deanin RD. 1975. Additives in plastics. Environ Health Persp 11:35-39.

De Quirós AR-B, Varela NV and Sendón R. 2015. Study of the migration of three model substances from low density polyethylene into food simulant and fruit juices. Beverages 1:159-168.

Del Carlo M, Pepe A, Sacchetti G, Compagnone D, Mastrocola D and Cichelli A. 2008. Determination of phthalate esters in wine using solid-phase extraction and gas chromatography-mass spectrometry. Food Chem 111:771-777.

DiGangi J, Schettler T, Cobbing M and Rossi M. 2002. Aggregate Exposures to Phthalates in Humans. Health Care Without Harm, Washington, DC. https://noharm-europe.org/sites/default/files/ documents-files/88/Agg_Exposures_to_Phthalates.pdf.

Dow. 2013. Product Safety Assessment: SARANEX ${ }^{\mathrm{TM}}$ Films. http:// www.dow.com/productsafety/assess/finder.htm\#S.

Dow. 2014. Regulatory Data Sheet: DOW DPDA-3135 NT 7 Medium Density Polyethylene Resin. https://www.dow.com/webapps/msds/ ShowPDF.aspx?id=090003e8808283f2.

Du C, Sabirova J, Soetaert W and Lin SKC. 2012. Polyhydroxyalkanoates production from low-cost sustainable raw materials. Curr Chem Biol 6:14-25.

DuPont. 2007. DuPont Sorona EP Thermoplastic Polymer (K-16836). http://www.engpolymer.co.kr/product/sorona/Sorona_EP_Brochure_1.pdf.

Easton S. 2010. Cork stoppers - with extra membrane? http://www. winewisdom.com/articles/closures/cork-stoppers-with-extramembrane/.

EFSA. Panel on Food Contact Materials, Enzymes, Flavourings and Processing Aids (CEF). 2015. Scientific opinion on the risks to public health related to the presence of bisphenol A (BPA) in foodstuffs. EFSA J 13:3978.

Elastocon. 2015. Elastocon OF65. Elastocon TPE Technologies. http:// www.elastocontpe.com/Selector-Guide/?DownloadID=52.

EU. 2008. European Union Updated Risk Assessment Report. Bisphenol A, CAS No: 80-05-7. Institute for Health and Consumer Protection, European Chemicals Bureau, European Commission Joint Research Centre, 3rd Priority List, Luxembourg.

EU. 2011. Commission Regulation (EU) No 10/2011 of 14 January 2011 on plastic materials and articles intended to come into contact with food (L 12/1, 15.1.2011). Official Journal of the European Union. http://eur-lex.europa.eu/LexUriServ/LexUriServ.do?uri=OJ:L:2011 :012:0001:0089:EN:PDF.

Fasano E, Bono-Blay F, Cirillo T, Montuori P and Lacorte S. 2012. Migration of phthalates, alkylphenols, bisphenol A and di(2-ethylhexyl) adipate from food packaging. Food Control 27:132-138. 
Fuller NJ, Lee SH and Buglass AJ. 2011. Other trace substances in alcoholic beverages. In Handbook of Alcoholic Beverages. Buglass AJ (ed.), pp. 1093-1110. John Wiley \& Sons, Hoboken, NJ.

Gander P. 2016. Bisphenol A-free can coatings in limbo. foodmanufacture.co.uk. https://www.foodmanufacture.co.uk/Article/2016/08/15/ Bisphenol-A-free-can-coatings-in-limbo.

Gennings C, Hauser R, Koch HM, Kortenkamp A, Lioy PJ, Mirkes PE and Schwetz BA. 2014. Chronic Hazard Advisory Panel on Phthalates and Phthalate Alternatives Final Report (with Appendices). U.S. Consumer Product Safety Commission Directorate for Health Sciences, Bethesda, MD.

Ghidossi R, Poupot C, Thibon C, Pons A, Darriet P, Riquier L, De Revel G and Mietton Peuchot M. 2012. The influence of packaging on wine conservation. Food Control 23:302-311.

Gill S. 2018. Is there an average weight for men? Med News Today. https://www.medicalnewstoday.com/articles/320917.php.

Goth H. 2007. New BASF plasticizers meet users' requirements. http:// www.plasticsportal.net/wa/plasticsEU en GB/portal/show/common/ plasticsportal_news/2007/07_287.

Graham PR. 1973. Phthalate ester plasticizers: Why and how they are used. Environ Health Persp 3:3-12.

Grignard E, Lapenna S and Bremer S. 2012. Weak estrogenic transcriptional activities of bisphenol A and bisphenol S. Toxicol In Vitro 26:727-731.

Grossman RF (ed.). 2008. Handbook of Vinyl Formulating, 2nd ed. John Wiley \& Sons, Hoboken, NJ.

Groth E and Silbergeld M. 1998. Endocrine Disrupting Chemicals in Plastic Wraps. Letter from the Consumers Union to FDA 5 June 1998. https://consumersunion.org/news/report-to-the-fda-regardingplastic-packaging/.

Guo Y, Zhang Z, Liu L, Li Y, Ren N and Kannan K. 2012. Occurrence and profiles of phthalates in foodstuffs from China and their implications for human exposure. J Agric Food Chem 60:6913-6919.

Howdeshell KL, Peterman PH, Judy BM, Taylor JA, Orazio CE, Ruhlen RL, Vom Saal FS and Welshons WV. 2003. Bisphenol A is released from used polycarbonate animal cages into water at room temperature. Environ Health Persp 111:1180-1187.

IPCS. 1992. Environmental Health Criteria 131: Diethylhexyl phthalate. International Programme on Chemical Safety. http://www.inchem. org/documents/ehc/ehc/ehc131.htm.

ISO. 2005. ISO No. 22000:2005 - Food safety management systemsRequirements for any organization in the food chain. International Organization for Standardization. https://www.iso.org/standard/35466. html.

Jennings R. 2012. The End of Wine Corks? RJonWine.com. http://www. rjonwine.com/wine-science/the-end-of-wine-corks/.

Johnston NE and Velikova N. 2016. Millennial Wine Consumers: Attitudes towards Alternative Wine Packaging. Texas Wine Marketing Research Institute, Lubbock, TX.

Jurica K, Brčić Karačonji I, Lasić D, Vukić Lušić D, Anić Jurica S and Lušić D. 2016. Determination of phthalates in plum spirit and their occurrence during plum spirit production. Acta Aliment Hung 45:141-148.

Karačonji IB, Jurica SA, Lasić D and Jurica K. 2017. Facts about phthalate toxicity in humans and their occurrence in alcoholic beverages. Arh Hig Rada Toksikol 68:81-92.

Klein R. 2011. Material properties of plastics. In Laser Welding of Plastics. pp. 3-69. Wiley-VCH Verlag GmbH \& Co. KGaA, Weinheim, Germany.

Kohn MC, Parham F, Masten SA, Portier CJ, Shelby MD, Brock JW and Needham LL. 2000. Human exposure estimates for phthalates. Environ Health Perspect 108:A440-A442.
Krimm S and Tobolsky AV. 1951. Quantitative x-ray studies of order in amorphous and crystalline polymers. Quantitative x-ray determination of crystallinity in polyethylene. J Polym Sci 7:57-76.

Lambert C and Larroque M. 1997. Chromatographic analysis of water and wine samples for phenolic compounds released from food-contact epoxy resins. J Chromatogr Sci 35:57-62.

Larroque M, Vian L, Blaise A and Brun S. 1988. Méthodes de dosage des monomères résiduels des résines époxydiques dans des simulants du vin. J Chromatogr A 445:107-117.

Latini G, De Felice C and Verrotti A. 2004. Plasticizers, infant nutrition and reproductive health. Reprod Toxicol 19:27-33.

Le HH, Carlson EM, Chua JP and Belcher SM. 2008. Bisphenol A is released from polycarbonate drinking bottles and mimics the neurotoxic actions of estrogen in developing cerebellar neurons. Toxicol Lett 176:149-156.

Leake LL. 2014. Wine quality and safety 101. Food Quality \& Safety. https://www.foodqualityandsafety.com/article/wine-quality-andsafety-101/

Leibowitz JN, Sarmiento R, Dugar SM and Ethridge MW. 1995. Determination of six common phthalate plasticizers in grain neutral spirits and vodka. J AOAC Int 78:730-735.

Li J, Su Q, Li KY, Sun CF and Zhang WB. 2013. Rapid analysis of phthalates in beverage and alcoholic samples by multi-walled carbon nanotubes/silica reinforced hollow fibre-solid phase microextraction. Food Chem 141:3714-3720.

Lithner D, Larsson $\AA$ and Dave G. 2011. Environmental and health hazard ranking and assessment of plastic polymers based on chemical composition. Sci Total Environ 409:3309-3324.

Lorber M, Schecter A, Paepke O, Shropshire W, Christensen K and Birnbaum L. 2015. Exposure assessment of adult intake of bisphenol A (BPA) with emphasis on canned food dietary exposures. Environ Int 77:55-62.

Lowell Center for Sustainable Production. 2011. Phthalates and their alternatives: Health and environmental concerns. Technical Briefing. Lowell Center for Sustainable Production, University of Massachusetts, Lowell.

Macek PV and Burkhardt CA. 2011. Analysis of low concentration BPA in consumer products by $\mathrm{GC} / \mathrm{MS}$ without derivatization (EAS2011GCMS-001). Shimadzu Scientific Instruments, Inc.

Martínez-Rodríguez AJ and Carrascosa AV. 2009. HACCP to control microbial safety hazards during winemaking: Ochratoxin A. Food Control 20:469-475.

Matsushima A et al. 2007. Structural evidence for endocrine disruptor bisphenol A binding to human nuclear receptor ERR gamma. J Biochem (Tokyo) 142:517-524.

McDonald GR et al. 2008. Bioactive contaminants leach from disposable laboratory plasticware. Science 322:9177.

Misko G. 2016. California to allow temporary point-of-sale, Prop 65 warnings for BPA exposure. Packaging Digest. http://www.packagingdigest.com/labeling/california-to-allow-temporary-point-of-saleprop-65-warnings-for-bpa-exposure-2016-05-16.

Molina-Molina JM, Amaya E, Grimaldi M, Sáenz JM, Real M, Fernández MF, Balaguer P and Olea N. 2013. In vitro study on the agonistic and antagonistic activities of bisphenol-S and other bisphenol-A congeners and derivatives via nuclear receptors. Toxicol Appl Pharmacol 272:127-136

Moreira MA, André LC and Cardeal ZL. 2013. Analysis of phthalate migration to food simulants in plastic containers during microwave operations. Int J Environ Res Public Health 11:507-526.

Müller AS. 2017. Test examines the chemicals in soda cans. Forbrugerrådet Tænk Kemis. As found on the website (http://kemi.taenk.dk/ bliv-groennere/test-examines-chemicals-soda-cans). 
Nara K, Nishiyama K, Natsugari H, Takeshita A and Takahashi H. 2009. Leaching of the plasticizer, acetyl tributyl citrate: (ATBC) from plastic kitchen wrap. J Health Sci 55:281-284.

Natural Resources Defense Council. 2011. Food Storage Containers. Nat Resour Def Counc. As found on the website (accessed 4 June 2014; website no longer available).

Noonan GO, Ackerman LK and Begley TH. 2011. Concentration of bisphenol A in highly consumed canned foods on the U.S. market. J Agric Food Chem 59:7178-7185.

Nordqvist C. 2018. Is moderate drinking good or bad for you? Medical News Today. https://www.medicalnewstoday.com/articles/265799.php.

NZ FSA. 2017. Generic HACCP Application: Production of Grape Wine. New Zealand Food Safety Authority. http://www.foodsafety. govt.nz/elibrary/industry/Generic_Haccp-Document_Provides.pdf.

O'Donnell B. 2016. Would you pop a can of Pinot? WineSpectator. http://www.winespectator.com/webfeature/show/id/Would-You-PopOpen-Up-Can-of-Pinot.

OEHHA. 2015. Bisphenol-A listed as known to the state of California to cause reproductive toxicity. Calif Environmental Protection Agency, Office of Environmental Health Hazard Assessment (OEHHA). (http:// oehha.ca.gov/prop65/CRNR_notices/list_changes/051115listBPA.html).

Pall Corporation. Cartridges and elements for wine production. (accessed 14 March 2014; website no longer available).

Paseiro-Cerrato R, DeVries J and Begley TH. 2017. Evaluation of short-term and long-term migration testing from can coatings into food simulants: Epoxy and acrylic-phenolic coatings. J Agric Food Chem 65:2594-2602.

Peyches-Bach A, Dombre C, Moutounet M, Peyron S and Chalier P. 2012. Effect of ethanol on the sorption of four targeted wine volatile compounds in a polyethylene film. J Agric Food Chem 60:6772-6781.

Pfannkoch E and Whitecavage J. 2002. Stir bar sorptive extraction from food simulating solvents: Preliminary studies. Global Analytical Solutions. Gerstel, Inc., Linthicum, MD.

Piringer OG and Baner AL (eds.). 2008. Plastic Packaging: Interactions with Food and Pharmaceuticals. 2nd ed. Wiley-VCH, Weinheim, Germany.

Pivnenko K, Pedersen GA, Eriksson E and Astrup TF. 2015. Bisphenol A and its structural analogues in household waste paper. Waste Manag 44:39-47.

Robertson GL. 2013. Food Packaging: Principles and Practice. CRC Press, Boca Raton, FL.

Russo M, Notardonato I, Cinelli G and Avino P. 2012. Evaluation of an analytical method for determining phthalate esters in wine samples by solid-phase extraction and gas chromatography coupled with iontrap mass spectrometer detector. Anal Bioanal Chem 402:1373-1381.

Rust S, Spivak C and Kissinger M. 2007. Bisphenol A is in you. Milwaukee Journal Sentinel. http://archive.jsonline.com/watchdog/ watchdogreports/34406849.html/.

Safer States. 2017. Bisphenol-A. Safer States. As found on the website (website no longer available).

Scheer R and Moss D. 2012. Is the plastic in boxed-wine liners BPAfree? Sci Am. http://www.scientificamerican.com/article/bpa-freeplastic-bags-in-boxed-wines/.

Sendón R, Sanches-Silva A, Bustos J, Martín P, Martínez N and Cirugeda ME. 2012. Detection of migration of phthalates from agglomerated cork stoppers using HPLC-MS/MS. J Sep Sci 35:1319-1326.

Shanks RA and Kong I. 2013. General purpose elastomers: Structure, chemistry, physics and performance. In Advances in Elastomers I. Visakh P et al. (eds.), pp. 11-45. Springer Berlin Heidelberg, Berlin, Heidelberg.

Sheftel VO. 2000. Indirect Food Additives and Polymers: Migration and Toxicology. CRC Press Boca Raton, FL.
Six T and Feigenbaum A. 2003. Mechanism of migration from agglomerated cork stoppers. Part 2: Safety assessment criteria of agglomerated cork stoppers for champagne wine cork producers, for users and for control laboratories. Food Addit Contam 20:960-971.

Six T, Feigenbaum A and Riquet A-M. 2002. Mechanism of migration from agglomerated cork stoppers: I. An electron spin resonance investigation. J Appl Polym Sci 83:2644-2654.

Smith JS and Hui YH (eds.). 2004. Food Processing: Principles and Applications. Blackwell Publishing, Oxford, UK.

Smith RA. 2013. Food Safety Modernization Act. Wines \& Vines. https://www.winesandvines.com/features/article/121416/Food-SafetyModernization-Act.

Steeman A. 2010. Wine bottle closures - the synthetic or plastic stopper for wine bottles (part 4). Best in Packaging. http://bestinpackaging. com/2010/05/20/wine-bottle-closures-the-synthetic-or-plastic-stopperfor-wine-bottles-part-4/.

Stoesser WC and Sommerfield EH. 1953. Method of making 4-tertiarybutylphenyl salicylate. US2654774A. https://patents.google.com/ patent/US2654774.

Teichgraeber T. 2005. Concrete fermenters: From old school to new world. Wines \& Vines. https://www.winesandvines.com/images/ W\&V11 05 Concrete Fermenters.pdf.

Teuten EL et al. 2009. Transport and release of chemicals from plastics to the environment and to wildlife. Philos T R Soc B 364:2027-2045.

Till DE, Reid RC, Schwartz PS, Sidman KR, Valentine JR and Whelan RH. 1982. Plasticizer migration from polyvinyl chloride film to solvents and foods. Food Chem Toxicol 20:95-104.

Timms BG, Howdeshell KL, Barton L, Bradley S, Richter CA and Vom Saal FS. 2005. Estrogenic chemicals in plastic and oral contraceptives disrupt development of the fetal mouse prostate and urethra. P Natl Acad Sci USA 102:7014-7019.

Trela B and Plank C. 2015. HACCP considerations: Plastic polymers in the wine industry. Wines Vines Pract Winery Vineyard. https://www. winesandvines.com/features/article/150511/HACCP+Considerations.

US DHHS (United States Department of Health and Human Services). 2011. 12th Report on Carcinogens (RoC) - National Toxicology Program. US Dep Health Hum Serv. as found on the website (https:// ntp.niehs.nih.gov/pubhealth/roc/index-1.html).

US EPA. 1993. Integrated Risk Information System: Bisphenol A. (CASRN 80-05-7): Oral RfD Assessment: Bisphenol A. US Environmental Protection Agency. http://www.epa.gov/iris/subst/0356.htm.

US EPA. 2009. National Primary Drinking Water Regulations. U.S. Environmental Protection Agency. https://www.epa.gov/sites/production/files/2016-06/documents/npwdr_complete_table.pdf.

US EPA. 2012. Phthalates Action Plan. United States Environmental Protection Agency. https://www.epa.gov/sites/production/files/2015-09/ documents/phthalates_actionplan_revised_2012-03-14.pdf.

US EPA. 2017a. Regional Screening Levels (RSLs) - Generic Tables (November 2017). US EPA[Data and Tools]. https://www.epa.gov/ risk/regional-screening-levels-rsls-generic-tables-november-2017.

US EPA. 2017b. Di(2-ethylhexyl)phthalate (DEHP); CASRN 117-81-7. U.S. Environmental Protection Agency, Integrated Risk Information System (IRIS). https://cfpub.epa.gov/ncea/iris/iris_documents/documents/subst/0014_summary.pdf.

US EPA. 2017c. Diethyl phthalate; CASRN 84-66-2. U.S. Environmental Protection Agency, Integrated Risk Information System (IRIS). https://cfpub.epa.gov/ncea/iris/iris_documents/documents/ subst/0226_summary.pdf.

US EPA. 2017d. Dibutyl phthalate; CASRN 84-74-2. U.S. Environmental Protection Agency, Integrated Risk Information System (IRIS). https://cfpub.epa.gov/ncea/iris/iris_documents/documents/ subst/0038_summary.pdf. 
US EPA. 2017e. Butyl benzyl phthalate; CASRN 85-68-7. U.S. Environmental Protection Agency, Integrated Risk Information System (IRIS). https://cfpub.epa.gov/ncea/iris/iris documents/documents/ subst/0293_summary.pdf.

US FDA. 1977a. Electronic Code of Federal Regulations (eCFR), Title 21-Food and Drugs, Part 177 - Indirect Food Additives: Polymers. https://www.accessdata.fda.gov/scripts/cdrh/cfdocs/cfcfr/CFRSearch. cfm?CFRPart $=177$.

US FDA. 1977b. Electronic Code of Federal Regulations (eCFR), Title 21-Food and Drugs, Section 175.300 - Resinous and polymeric coatings. https://www.accessdata.fda.gov/scripts/cdrh/cfdocs/cfCFR/ CFRSearch.cfm? fr $=175.300$.

US FDA. 2007a. Ingredients, Additives, GRAS \& Packaging - Guidance for Industry: Preparation of Premarket Submissions for Food Contact Substances (Chemistry Recommendations). https://www. fda.gov/Food/GuidanceRegulation/GuidanceDocumentsRegulatoryInformation/IngredientsAdditivesGRASPackaging/ucm081818.htm.

US FDA. 2007b. Guidance and Regulation - Guidance for Industry: Preparation of Premarket Submissions for Food Contact Substances (Chemistry Recommendations). https://www.fda.gov/Food/GuidanceRegulation/ucm081818.htm.

US FDA. 2013a. CFR - Code of Federal Regulations Title 21: Sec. 177.2600 Rubber articles intended for repeated use. http://www.accessdata.fda.gov/scripts/cdrh/cfdocs/cfcfr/cfrsearch.cfm?fr=177.2600.

US FDA. 2013b. CFR - Code of Federal Regulations Title 21: Sec. 165.110 Requirements for specific standardized beverages: Bottled water. http://www.accessdata.fda.gov/scripts/cdrh/cfdocs/cfcfr/ CFRSearch.cfm?fr $=165.110$.

US FDA. 2014. Food Additives \& Ingredients - Bisphenol A (BPA). https://www.fda.gov/Food/IngredientsPackagingLabeling/FoodAdditivesIngredients/ucm166145.htm.
Vieira MGA, da Silva MA, dos Santos LO and Beppu MM. 2011. Natural-based plasticizers and biopolymer films: A review. Eur Polym J 47:254-263.

Vom Saal FS, Nagel SC, Coe BL, Angle BM and Taylor JA. 2012. The estrogenic endocrine disrupting chemical bisphenol A (BPA) and obesity. Mol Cell Endocrinol 354:74-84.

Wagner M and Oehlmann J. 2009. Endocrine disruptors in bottled mineral water: Total estrogenic burden and migration from plastic bottles. Environ Sci Pollut Res Int 16:278-286.

White JL and Spruiell JE. 1981. Specification of biaxial orientation in amorphous and crystalline polymers. Polym Eng Sci 21:859-868.

Wool RP and Sun XS. 2005. Bio-based Polymers and Composites. Elsevier Academic Press, Amsterdam, Boston.

Yano K, Hirosawa N, Sakamoto Y, Katayama H, Moriguchi T, Joung KE, Sheen YY and Asaoka K. 2002. Phthalate levels in beverages in Japan and Korea. Bull Environ Contam Toxicol 68:463-469.

Yinan G. 2012. China probes liquor containing excessive plasticizer. People's Daily Online English. http://english.peopledaily.com. cn/90782/8030116.html.

Yoshida $\mathrm{S}$ et al. 2016. A bacterium that degrades and assimilates poly(ethylene terephthalate). Science 351:1196-1199.

Zapel C. 2011. Behind the science: Is there BPA in my wine? Wine Spectator. http://www.winespectator.com/webfeature/show/id/45545.

Zheng Y, Monty J and Linhardt RJ. 2015. Polysaccharide-based nanocomposites and their applications. Carbohydr Res 405:23-32.

Zhou Y, Wang H, Chen Y and Jiang Q. 2011. Environmental and food contamination with plasticisers in China. Lancet 378:e4.

Zhu J. 2012. Plasticizers found in baijui. China Daily. http://www. chinadaily.com.cn/china/2012-11/20/content_15946156.htm. 